\title{
KESEJAHTERAAN DENGAN PRESTASI KERJA
}

\author{
Agus Dudung \\ Email : agus.dudung@yahoo.co.id \\ Program Studi Pendidikan Teknik Mesin \\ Fakultas Teknik, Universitas Negeri Jakarta \\ Jl. Rawamangun Muka, Jakarta Timur. 13220
}

\begin{abstract}
Abstrak
Penelitian ini bertujuan untuk mengetahui apakah ada hubungan positif antara kesejahteraan dengan prestasi kerja. Uji hipotesis penelitian dengan korelasi Product Moment untuk mendapatkan koefisien korelasi dan untuk menentukan kesimpulan digunakan rumus Student-t. Hasil didapat koefisien korelasi adalah 0,08 dengan harga t didapat 6,67 . Sedangkan $t$ tabel dengan taraf signifkansi $5 \%$ dan $\mathrm{dk}=34$ adalah 1,70 , ini berarti $t$ hitung lebih besar dari t tabel sehingga dapat menerima hipotesis alternatif $\mathrm{Hi}$ dan menolak hipotesis Ho. Kesimpulan penelitian ini terdapat korelasi positif antara kesejahteraan dengan prestasi kerja.
\end{abstract}

Kata kunci: Kesejahteraan dan Prestasi kerja

\begin{abstract}
This study aims to find out if there's a positive relationship between welfare and the work performance. The hypothesis research test by Product Moment correlation to get the correlation coefficient and to determine the conclusions used Student-t formula. The results obtained that correlation coefficient is 0.08 with the t-test 6.67 . While t-table with a significance level of $5 \%$ and $\mathrm{dk}=34$ is 1.70 , this means that $\mathrm{t}$-count is higher than t-table so the alternative hypothesis $\mathrm{Hi}$ accepted and Ho hypothesis was rejected. The conclusion of this study is that there is a positive correlation between welfare and work performance.
\end{abstract}

Keynote: Welfare, Work Performance

\section{PENDAHULUAN}

Terciptanya kesejahteraan merupakan hal yang diinginkan semua manusia. Hasibuan (2003: 187), mengemukakan bahwa kesejahteraan yang diberikan hendaknya bermanfaat dan mendorong untuk tercapainya tujuan organisasi, pegawai, dan masyarakat serta tidak melanggar peraturan legal pemerintah. Asas kesejahteraan adalah keadilan dan kelayakan serta tidak melanggar peraturan legal pemerintah. Jenis-jenis kesejahteraan yang diberikan adalah finansial dan non finansial yang bersifat ekonomis, serta pemberian fasilitas dan pelayanan. Pemberian kesejahteraan perlu diprogram dengan sebaikbaiknya, supaya bermanfaat dalam mendukung tujuan organisasi, pegawai, dan masyarakat. Program kesejahteraan harus berasaskan keadilan dan kelayakan. Berpedoman kepada peraturan legal pemerintah dan didasarkan atas kemampuan organisasi. Hal ini penting supa ya kesejahteraan yang pernah diberikan tidak ditiadakan karena akan mengakibatkan pegawai malas. disiplinnya merosot kerusakan meningkat, 
bahkan turnover meningkat. Program kesejahteraan harus diinformasikan secara terbuka dan jelas waktu pemberiannya tepat dan sesuai dengan kebutuhan pegawai.

Selain kesejahteraan yang baik, kompensasi merupakan hal yang penting untuk peningkatan prestasi kerja. Menurut Panggabean (2004: 75), mengemukakan bahwa kompensasi juga disebut penghargaan dan dapat didefinisikan sebagai setiap bentuk penghargaan yang diberikan kepada pegawai sebagai balas jasa atas konstribusi yang mereka berikan kepada organisasi. Hani T. Handoko (2001 : 155) menyatakan bahwa kompensasi adalah segala sesuatu yang diterima para pegawai sebagai balas jasa untuk kerja mereka. Kompensai dapat diberikan dalam berbagai macam bentuk, seperti dalam bentuk material, dan bentuk pemberian fasilitas, dan dalam bentuk pemberian kesempatan berkarier.

Menurut Notoatmodjo, (2009 : 142), mengemukakan bahwa kompensasi adalah segala sesuatu yang diterima oleh pegawai sebagai balas jasa untuk kerja atas pengabdian mereka. Sedangkan Edy Sutrisno (2009 : 205) mengemukakan bahwa kompetensi adalah semua jenis penghargaan yang berupa uang atau bukan uang yang diberikan kepada pegawai secara layak dan adil atau jasa mereka dalam mencapai tujuan organisasi. Selanjutnya Tohardi (2002) dikutip oleh Edy Sutrisno(200 9 : 199) mengemukakan bahwa kompensasi dihitung berdasarkan evaluasi pekerjaan, perhitungan kompensai berdasarkan evaluasi pekerjaan tersebut dimasudkan untuk mendapatkan pemberian kompensasi yang mendekati kelayakan (wortb) dan keadilan (equitu).

Bryars dan Rue dikutip oleh Edy Sutrisno (2009:164), mengartikan bahwa Prestasi adalah tingkat kecakapan seseorang pada tugas-tugas yang mencakup pada pekerjaannya. Pengertian tersebut menunjukkan pada bobot kemampuan individu di dalam memenuhi ketentuan-ketentuan yang ada di dalam pekerjaannya. Sedangkan prestasi kerja adalah hasil upaya seseorang yang ditentukan oleh kemampuan karakteristik pribadinya serta persepsi terhadap perannya dalam pekerjaan itu.

Adapun Maier dikutip oleh Muh. As'ad (2001:48), menyatakan bahwa merit lebih merupakan aspek umum dari pada profeciency tersebut, sedangkan produktivitas kerja adalah perbandingan antara input dan output. Selanjutnya Edy Sutrisno (2009:164) mengartikan bahwa faktor-faktor lingkungan ini tidak langsung menentukan prestasi kerja seseorang, tetapi mempengaruhi faktor-faktor individu. McCormick dan Tiffin dikutip oleh Edy Sutrisno (2009:166) mengemukakan bahwa prestasi kerja merupakan hasil dari gabungan variabel individual dan variabel fisik dengan pekerjaan serta variabel organisasi dan sosial.

Dengan berdasarkan latar belakang di atas, maka peneliti melakukan penelitian Kesejahteraan terhadap Prestasi Kerja. Dengan mengacu pada identifikasi masalah di atas, maka perumusan masalah penelitian adalah sebagai berikut, Bagaimana pengaruh kesejahteraan terhadap prestasi kerja?

\section{METODE PENELITIAN}

Penelitian ini bertujuan untuk mengetahui adanya korelasi positif antara kesejateraan dengan prestasi kinerja

Metode penelitian yang digunakan merupakan metode deskriptif dengan studi korelasi yang bertujuan menetapkan besarnya korelasi antara varaiabel-variabel dengan sistem pendekatannya adalah one shot model sehingga satu kali pengumpulan data pada suatu saat. Adapun teknik analisis digunakan Kuder Richardson (K-R) 21.

Populasi penelitian seluruh karyawan FT.UNJ diambil secara acak sebanyak 36 orang.

Adapun variabel bebas $(\mathrm{X})$ adalah Kesejahteraan dan variabel terikat $(\mathrm{Y})$ adalah Prestasi kerja.

Reliabilitas intrumen dari hasil uji coba untuk kesejahteraan 0,771 dan tes prestasi kerja 0,653 sehingga dapat dikatakan reliabel. 
Sedangkan untuk menganalisis data digunakan korelasi Product Moment dari Pearson. Koefisien korelasi yang diperoleh diuji keberartiannya untuk menentukan generalisasi atau kesimpulan pada populasi penelitian dan keberartian di uji dengan uji-t pada derajat kebebasan $(\mathrm{dk})=\mathrm{n}-2$, serta $\alpha=0,05$.

\section{HASIL PENELITIAN}

Dari pengolahan data kesejahteraan diperoleh, hasil penelitian ini sekor tertinggi yang diperoleh adalah 73,33 dan terendah 43,33 . maka rata-ratanya adalah 58,5178 . Dari data di atas dibuat tabel distribusi frekuensi sebagai berikut:

Tabel 1. Distribusi Frekuensi Kesejahteraan

\begin{tabular}{|c|c|c|c|c|c|c|}
\hline No & Interval kelas & $\begin{array}{c}\text { Titik } \\
\text { tengah }\end{array}$ & $\begin{array}{c}\text { Batas } \\
\text { nyata }\end{array}$ & $\begin{array}{c}\text { Frekuensi } \\
\text { Absolut }\end{array}$ & $\begin{array}{c}\text { Frekuensi } \\
\text { Kumulatif }\end{array}$ & $\begin{array}{c}\text { Frekuensi } \\
\text { Relatif } \\
(\%)\end{array}$ \\
\hline 1 & $43,33-47,33$ & 45,33 & 42,83 & 4 & 4 & 11,11 \\
\hline 2 & $48,33-52,33$ & 50,33 & 47,63 & 4 & 8 & 11,1 \\
\hline 3 & $53,33-57,33$ & 55,33 & 52,83 & 9 & 17 & 25 \\
\hline 4 & $58,33-62,33$ & 60,33 & 57,83 & 10 & 27 & 27,78 \\
\hline 5 & $63,33-67,33$ & 65,33 & 62,83 & 4 & 31 & 11,11 \\
\hline 6 & $68,33-72,33$ & 70,33 & 67,63 & 3 & 34 & 8,33 \\
\hline 7 & $73,33-77,33$ & 75,33 & 72,83 & 2 & 36 & 5,56 \\
\hline & & & 77,83 & & & \\
\hline
\end{tabular}

Dari tabel distribusi frekuensi di atas, terlihat bahwa sebagian besar mencapai sekor $58,33-62,33$ yaitu $27,78 \%$, tertinggi yang diperoleh antara 73,33 - 77,33 sebanyak 2 karyawan (5,56\%), sedangkan nilai terendah antara $43,33-47,33$ sebanyak 4 atau $11,11 \%$.

Dari pengolahan data prestasi kerja, hasil penelitian ini sekor tertinggi yang diperoleh adalah 70 dan terendah 35 , dan rata-rata adalah 72,78 . Dari data yang diperoleh dapat dibuat tabel distribusi frekuensi sebagai berikut:

Tabel 2. Distribusi Frekuensi Prestasi kerja

\begin{tabular}{|c|c|c|c|c|c|c|}
\hline No & $\begin{array}{c}\text { Interval } \\
\text { Kelas }\end{array}$ & $\begin{array}{c}\text { Titik } \\
\text { tengah }\end{array}$ & $\begin{array}{c}\text { Batas } \\
\text { nyata }\end{array}$ & $\begin{array}{c}\text { Frekuensi } \\
\text { Absolut }\end{array}$ & $\begin{array}{c}\text { Frekuensi } \\
\text { Komulatif }\end{array}$ & $\begin{array}{c}\text { Frekuensi } \\
\text { Relatif } \\
(\%)\end{array}$ \\
\hline 1 & $35-40$ & 37,5 & 34,5 & 4 & 4 & 11,12 \\
\hline 2 & $41-46$ & 43,5 & 40,5 & 7 & 11 & 19,44 \\
\hline 3 & $47-52$ & 49,5 & 46,5 & 7 & 18 & 19,44 \\
\hline 4 & $53-58$ & 55,5 & 52,5 & 7 & 25 & 19,44 \\
\hline 5 & $59-64$ & 61,5 & 58,5 & 7 & 32 & 19,44 \\
\hline 6 & $65-70$ & 67,5 & 64,5 & 4 & 38 & 11,12 \\
\hline & & & 70,5 & & & \\
\hline
\end{tabular}

Dari tabel distrbusi frekuensi di atas, terlihat bahwa terdapat empat interval kelas yaitu 41 - 48, $47-52,53-58$, dan $59-64$ yang mempunyai frekuensi absolut yang sama masingmasing 7. Sekor tertinggi yang diperoleh antara $65-70$ sebanyak 4 karyawan. Sedangkan nilai terendah yang diperoleh antara 35 - 40 sebanyak 4 karyawan. Dalam penelitian ini untuk menguji normalitas data digunakan uji Chi Kuadrat. Dari hasil perhitungan pengujian normalitas data terlihat pada tabel sebagai berikut:

Tabel 3. Hasil Uji Normalitas

\begin{tabular}{|c|c|c|c|c|}
\hline Sekor & $\mathrm{X}^{2}$ Hitung & $\mathrm{X}^{2}$ tabel & $\mathrm{Dk}$ & $\alpha$ \\
\hline Kesejahteraan & 5,9 & 9,49 & 4 & $5 \%$ \\
\hline
\end{tabular}




\begin{tabular}{|l|l|l|l|l|}
\hline Prestasi Kerja & 3,93 & 7,81 & 3 & $5 \%$ \\
\hline
\end{tabular}

Dari tabel di atas, data kesejahteraan didapat $X^{2}$ hitung yang diperoleh 5,9, sedangkan $X^{2}$ tabel pada taraf $\alpha=5 \%$ dan $d k=4$ adalah 9,49 sehingga $X^{2}$ hitung lebih kecil dari $X^{2}$ tabel. Maka data berdistribusi normal.

Pada tabel yang sama, prestasi kerja $\mathrm{X}^{2}$ hitung adalah 3,93 , sedangkan $\mathrm{X}^{2}$ tabel pada $\alpha$ $=5 \%$ dan $\mathrm{dk}=3$ adalah 7,81, sehingga $X^{2}$ hitung lebih kecil dari $X^{2}$ tabel, maka data berdistribusi normal.

Uji linieritas dilakukan dengan menggunakan uji $F$ pada taraf signifikansi $5 \%$. Jumlah data $(\mathrm{K})=8$, derajat kebebasan untuk pembilang $\mathrm{dk}=\mathrm{K}-2=6$, derajat kebebasan untuk penyebut $\mathrm{dk}=\mathrm{n}-\mathrm{k}=28$, maka dapat dilihat tabel berikut ini :

Tabel. 4. Uji Linieritas Variabel bebas terhadap Variabel terikat.

\begin{tabular}{|c|c|c|c|c|c|}
\hline Sumber Varians & Dk & JK & RJK & F hitung & $F_{\text {tabel }}$ \\
\hline Tuna Cocok & 6 & $-1664,89$ & $-277,48$ & \multirow{2}{*}{$-3,02$} & 2,115 \\
\hline Kekeliruan & 28 & 2572,22 & 91,02 & & 2,22 \\
\hline
\end{tabular}

Dari tabel di atas terlihat bahwa data variabel bebas terhadap variabel terikat adalah linier karena $F$ hitung lebih kecil dari $F$ tabel dengan $\alpha=5 \%$ dan derajat kebebasan dk (6/28).

Setelah dilakukan analisis data berikutnya dilakukan uji hipotesis dengan menggunakan teknik analisis korelasi Product Moment diperoleh harga $r=0,80$, dan hasil uji hipotesis dapat dilihat pada tabel berikut ini:

Tabel 5. Uji Hipotesis Penelitian

\begin{tabular}{|c|c|c|c|c|c|}
\hline $\mathrm{R}$ & $\mathrm{\alpha}$ & $\mathrm{N}$ & $\mathrm{Dk}=\mathrm{N}-2$ & T hitung & T tabel \\
\hline 0,80 & 0,05 & 36 & 34 & 6,67 & 1,70 \\
\hline
\end{tabular}

Dari tabel di atas dapat dilihat bahwa harga $r$ hitung dianalisis dengan rumus Student- $t$ dan dengan derajat kebebasan $(\mathrm{dk})=\mathrm{N}-2$ diperoleh $\mathrm{t}$ hitung $=6,67$. menurut tabel distribusi $\mathrm{t}$ untuk $\mathrm{dk}=34$ dan $\alpha=5 \%$ diperoleh $\mathrm{t}$ tabel $=1,70$.

Dari data di atas dapat dilihat bahwa t hitung lebih besar dari t tabel, maka hipotesis Ho ditolak dan menerima hipotesis alternatif $\mathrm{Hi}$ yang menyatakan terdapat korelasi positif antara kesejahteraan dengan prestasi kerja karyawan FT.UNJ

\section{PEMBAHASAN}

Dari pengujiam hipotesis terlihat bahwa terdapat hubungan positif antara kesejahteraan dengan prestasi kerja. Apabila karyawan mendapat sekor kesejahteraan yang baik, berarti mendapat sekor yang baik pula pada prestasi kerja.

Kesejahteraan pada dasarnya tidak diperoleh secara khusus, tetapi dapat berpengaruh terhadap prestasi kerja. Kesejahteraan karyawan sangat dibutuhkan seperti persamaan yang ditunjukkan pada hasil perhitungan yaitu: $\hat{Y}=3,63+0,8 x$, dimana makin besar kesejahteraan semakin besar pula tingkat prestasi belajar

\section{KESIMPULAN}

Dari hasil penelitian ini dapat disimpulkan bahwa terdapat hubungan positif antara kesejahteraan dengan prestasi kerja karyawan FT. UNJ. Hal ini berarti semakin tinggi kesejahteraan karyawan semakin meningkat prestasi kerja.

Kesejahteraan karyawan faktor yang menentukan terhadap keberhasilan prestasi kerja, karena kesejahteraan karyawan merupakan salah satu kemampuan dasar yang harus dimiliki karyawan. 


\section{DAFTAR PUSTAKA}

E. Mulyasa, (2003), Kompetensi Konsep, Karakteristik dan Implementasi, Bandung : Remaja Rosdakarya.

Edy Sutrisno, (2009), Manajemen Sumber Daya Manusia, Jakarta : Kencana Media Group. , (2010), Budaya Organisasi, Jakarta : Kencana Prenada Media Group.

I.G. Wursanto, (2000), Managemen Kepegawaian. Kenisisus : Yogyakarta.

Moeheriono (2009), Pengukuran Kinerja Berbasis Kompetensi, Bandung Ghalia Indonesia.

Moh. Pabundu Tika (2006), Budaya Organisasi dan Peningkatan Kinerja Perusahaan, Jakarta : Bumi Aksara.

Mohamad Mahsun (2009), Pengukuran Kinerja Sektor Publik, Yogyakarta : BPFE.

Panji Anoraga, (2001), Psikologi Kerja, Jakarta, Rineka Cipta.

Panggabean, Mutiara S. (2004), Manajemen Sumber Daya Manusia, Ciawi-Bogor,Ghalia Indonesia.

Simanjuntak, Payaman J. (2005), Manajemen dan Evaluasi Kinerja, Jakarta : FEUI.

Suyadi Prawirosentono (2000), Kebijakan Kinerja Karyawan, Yogyakarta : BPFE.

Tohardi, Ahmad, (2002). Pemahaman Praktis Manejemen Sumber Daya Manusia, Bandung: CV. Mandar Maju.

Wibowo, (2007), Manajemen Kinerja, Jakarta : Raja Grafindo Persada. 